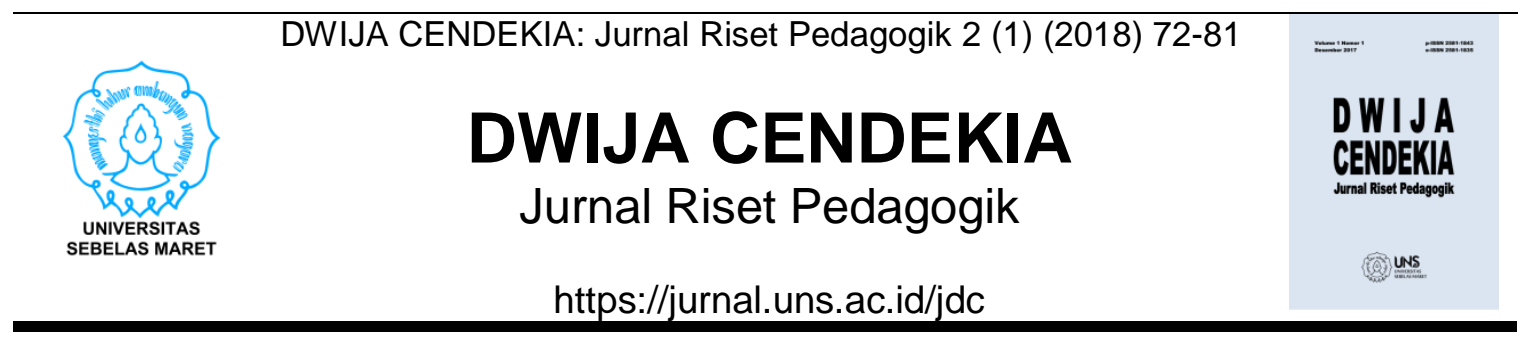

\title{
PEMBELAJARAN DENGAN PENDEKATAN DISCOVERY PADA BANGUN RUANG SISI DATAR DI SEKOLAH DASAR
}

\section{Trisniawati}

\section{Universitas Sarjanawiyata Tamansiswa}

\section{Sejarah Artikel}

Diterima 1 Juni 2017

Disetujui 20 Agustus 2017

Diterbitkan 1 Agustus 2018

Kata Kunci

pembelajaran matematika, pendekatan discovery,

bangun ruang.

\begin{abstract}
Abstrak
Di dunia yang terus berubah, mereka yang memahami dan dapat mengerjakan matematika akan memiliki kesempatan dan pilihan yang banyak dalam menentukan masa depannya. Oleh karena itu, untuk menguasai dan menciptakan ilmu pengetahuan dan teknologi informasi serta mampu bertahan hidup pada keadaan yang selalu berubah dan kompetitif di masa depan diperlukan penguasaan matematika yang kuat sejak dini. Melihat begitu pentingnya matematika, maka pembelajaran matematika diberikan di semua jenjang pendidikan di Indonesia mulai dari sekolah dasar. Pembelajaran matematika hendaknya berpusat pada siswa dengan menggunakan berbagai macam pendekatan dan metode. Siswa dituntut mampu menemukan konsep dalam pembelajaran matematika. Siswa dituntut untuk dapat menemukan konsep sendiri melalui pembelajaran yang bermakna salah satunya pembelajaran dengan pendekatan discovery. Pendekatan discovery merupakan suatu pendekatan belajar dimana siswa dituntut mampu menemukan suatu konsep dalam belajar. Selain itu pembelajaran yang mengaitkan antara materi yang diajarkan dengan kehidupan sehari-hari dimana siswa mengamati, menggolongkan, membuat dugaan, menjelaskan, menganalisis, memverifikasi, membuat kesimpulan suatu konsep dalam belajar termasuk pada bangun ruang sisi datar di sekolah dasar.

\section{Cara Mengutip}

Trisniawati. (2018). Pembelajaran dengan Pendekatan Discovery pada Bangun Ruang Sisi Datar di Sekolah Dasar. DWIJA CENDEKIA: Jurnal Riset Pedagogik, 2 (1), 72-81
\end{abstract}

Korespondensi Penulis trisniawati.87@gmail.com
p-ISSN 2581-1843

e-ISSN 2581-1835 


\section{PENDAHULUAN}

Matematika merupakan pengetahuan yang mempunyai peran penting dalam perkembangan teknologi. Matematika juga digunakan dalam kehidupan sehari-hari dan dalam berbagai bidang ilmu lainnya, seperti ekonomi, fisika, biologi, dan kimia. Dengan demikian, pembelajaran matematika di sekolah memegang peranan penting dalam sistem pendidikan, karena pembelajaran matematika merupakan salah satu cara yang formal untuk meningkatkan kemampuan matematika dalam kehidupan masyarakat, khususnya masyarakat usia sekolah. Mengingat matematika begitu berperan dalam perkembangan zaman, pendidikan matematika dituntut untuk mempersiapkan diri dalam rangka menghadapi perkembangan ilmu pengetahuan dan teknologi. Pendidikan matematika harus mampu membekali peserta didik dengan pengetahuan dan keterampilan yang mampu menjawab tantangan di era globalisasi. Pembelajaran matematika yang dilaksanakan di setiap tingkatan pendidikan seharusnya berdasarkan pada Standar Nasional Pendidikan
(SNP), yang salah satu unsurnya menjelaskan tentang standar isi mata pelajaran.

Marpaung (2001:2) menyatakan bahwa proses pembelajaran selama ini terpusat pada guru dan bersifat mekanistik yaitu guru aktif menerangkan, siswa pasif mengikuti apa yang disampaikan oleh guru. Pemahaman yang diperoleh siswa hnya bersifat instrumental, yaitu siswa dapat menggunakan rumus-rumus untuk menyelesaikan soal tetapi tidak mengerti darimana rumus itu diperoleh dan mengapa rumus itu digunakan. Dengan strategi seperti ini siswa menerima pelajaran matematika secara pasif dan bahkan hanya menghafal rumus-rumus tanpa memahami makna dan manfaat dari apa yang dipelajari. Akibatnya prestasi belajar matematika di sekolah masih relatif rendah dan tidak mengalami peningkatan yang berarti. Dalam hal ini perlu adanya pendekatan yang baru dalam pembelajaran matematika untuk mendukung pembelajaran aktif dan berpusat ke peserta didik. Salah satunya adalah pembelajaran dengan pendekatan discovery.

\section{PEMBAHASAN}

\section{Pengertian Discovery}

Pendekatan

Pembelajaran

merupakan suatu pendekatan belajar dimana siswa dituntut mampu menemukan suatu konsep dalam belajar. Siswa dituntut aktif dalam proses belajar mengajar. Dengan pendekatan discovery ini, guru harus memperhatikan siswa yang cerdas dan kurang cerdas. Discovery diterjemahkan sebagai penemuan. Menurut Sund (Roestiyah, 2008 : 20) discovery adalah proses mental dimana siswa mampu mengasimilasi sesuatu konsep atau prinsip. Yang dimaksud dengan proses mental tersebut antara lain ialah: mengamati, mencerna, mengerti, menggolong-golongkan, membuat dugaan, menjelaskan, mengukur, membuat kesimpulan dan sebagainya. Selain itu Lefrancois 
(2000: 209) pembelajaran discovery adalah pembelajaran yang terjadi ketika siswa tidak disajikan materi pelajaran secara langsung melainkan diminta untuk menemukan sendiri hubungan yang ada antara informasiinformasi yang diberikan.

$$
\text { Elliot }
$$
(2000:

mengemukakan bahwa "encouraging discovery causes students not only to organize material to determine regularities and relationships but also to avoid the passivity that blinds them to the use of the information learned". Artinya mendorong pembelajaran discovery menyebabkan siswa tidak hanya mengatur materi untuk menentukan keteraturan dan hubungan tetapi juga untuk menghindari kegiatan yang pasif yang membutakan mereka terhadap penggunaan informasi dipelajari. Selain itu Moore (2009: 182) mengemukakan bahwa pembelajaran discovery juga mendorong pengembangan keterampilan sosial yang positif. Penemuan mengharuskan siswa belajar bekerja sama. Mereka harus mengembangkan keterampilan dalam perencanaan, mengikuti prosedur yang sesuai, dan bekerja bersama menuju keberhasilan untuk menyelesaikan tugas mereka.

Pembelajaran discovery adalah komponen penting dari pendekatan konstruktivis modern yang memiliki sejarah panjang dalam inovasi pendidikan. Menurut Bergstrom \& O'Brien (Slavin, 2006: 245), pada pembelajaran discovery siswa didorong untuk belajar secara aktif dengan konsepkonsep dan prinsip-prinsip, dan guru mendorong siswa memperoleh pengalaman dan melakukan percobaan yang memungkinkan mereka menemukan sendiri prinsip-prinsip. Seperti yang dikemukakan Alfieri (2010: 2) mengemukakan bahwa sebuah tinjauan literatur menunjukkan bahwa pembelajaran penemuan terjadi setiap kali siswa tidak diberikan informasi tujuan atau pemahaman konseptual dan harus menemukannya sendiri dan dengan hanya menyediakan bahan-bahan. Selain itu Schunk (2008: 280) berpendapat :

Discovery learning refers to obtaining knowledge for oneself (Bruner, 1961). Discovery is important for cognitive learning - especially of complex forms - because it involves constructing and testing hypotheses rather than simply reading or listening to teacher presentations. Discovery is a type of inductive reasoning, because students move from studying specific examples to formulating general rules, concepts, and principles.

Artinya pembelajaran discovery mengacu pada memperoleh pengetahuan untuk diri sendiri. Discovery ini penting untuk belajar kognitif terutama bentuk-bentuk rumit karena melibatkan membangun dan menguji hipotesis, bukan hanya membaca atau mendengarkan presentasi guru. Discovery adalah jenis penalaran induktif, karena siswa menggeneralisasikan aturan-aturan umum, konsep, dan prinsip dengan mempelajari contoh-contoh spesifik. Menurut Coffey tujuan pembelajaran discovery adalah pemahaman 
yang

mendalam,

mengembangkan keterampilan

meta kognitif, dan mendorong tingkat tinggi keterlibatan siswa. Lebih lanjut Brown (2007: 313) mengemukakan komunikasi adalah proses penyelidikan yang paling besar dan merupakan bagian terbesar dari discovery. Juga, tipe yang digambarkan oleh Strike dalam Brown (2007: 313) menyiratkan bahwa siswa harus "tahu" sesuatu sebelum mereka dapat "menemukan" sesuatu. Materi, pengetahuan, fakta, dan proses adalah bagian terbesar dari discovery.

2. Karakteristik Pembelajaran Discovery

Secara garis besar prosedur pendekatan discovery menurut Syaiful Bahri Djamarah (2006: 1920) adalah sebagai berikut :

a. Stimulation

Guru mulai dengan bertanya mengajukan persoalan, atau menyuruh peserta didik membaca atau mendengarkan uraian yang memuat persoalan.

b. Problem statement Peserta didik diberi kesempatan

mengidentifikasi berbagai permasalahan, sebanyak mungkin memilihnya yang dipandang paling menarik dan fleksibel untuk dipecahkan. Permasalahan yang dipilih ini selanjutnya harus dirumuskan dalam bentuk pertanyaan atau hipotesis (pertanyaan sebagai jawaban sementara atas pertanyaan tersebut).

c. Data collection
Untuk menjawab

pertanyaan atau

membuktikan benar

tidaknya hipotesis itu, peserta didik diberi kesempatan untuk mengumpulkan berbagai informasi yang relevan, dengan jelas membaca literatur, mengamati objeknya, mewawancarai orang sumber, mencoba (uji coba) sendiri, dan sebagainya.

d. Data processing

Semua informasi (hasil bacaan wawancara, observasi, dan sebagainya) itu diolah, diacak, diklasifikasikan,

ditabulasikan, bahkan kalau perlu dihitung dengan cara tertentu serta ditafsirkan pada tingkat kepercayaan tertentu.

e. Verification

Berdasarkan hasil pengolahan dan tafsiran atau informasi yang ada tersebut (available information), pertanyaan atau hipotesis yang telah dirumuskan terdahulu itu kemudian dicek, apakah terjawab atau, dengan kata lain, terbukti atau tidak.

f. Generalization

Tahap selanjutnya, berdasarkan hasil verifikasi tadi siswa belajar menarik generalisasi atau kesimpulan tertentu.

Dalam pelaksanaannya, pendekatan discovery membutuhkan metode belajar yang mengarahkan kepada keaktifan siswa. Metode pelajaran yang dapat digunakan seperti 
metode eksperimen dan demonstrasi.

berkeinginan untuk mengetahui keadaan sekitarnya dengan baik.

3. Kelebihan

Pembelajaran Discovery

Kelebihan dari pendekatan discovery (Roestiyah, 2008 : 2021) adalah :

a. Membantu

siswa mengembangkan; memperbanyak kesiapan; serta penguasaan ketrampilan dalam kognitif/pengenalan siswa

b. Siswa memperoleh pengetahuan yang bersifat sangat pribadi/individual sehingga dapat kokoh/mendalam tertinggal dalam jiwa siswa tersebut.

c. Dapat membangkitkan kegairahan belajar siswa

d. Memberikan kesempatan kepada siswa untuk berkembang dan maju sesuai dengan kemampuannya masing-masing.

e. Mampu mengarahkan cara siswa belajar, sehingga lebih memiliki motivasi yang kuat untuk belajar lebih giat.

f. Membantu siswa untuk memperkuat dan menambah kepercayaan pada diri sendiri dengan proses penemuan sendiri.

g. Berpusat pada siswa dan tidak pada guru. Guru hanya sebagai teman belajar saja, membantu bila diperlukan.

Adapun kekurangan dari pendekatan discovery (Roestiyah, 2008: 21) antara lain:

a. Pada siswa harus ada kesiapan dan kematangan mental untuk cara belajar ini. Siswa harus berani dan b. Bila kelas terlalu besar penggunaan teknik ini kurang berhasil.

c. Bagi guru dan siswa yang sudah terbiasa dengan perencanaan dan pengajaran tradisional mungkin akan sangat kecewa bila diganti dengan teknik penemuan.

d. Dengan teknik ini ada yang berpendapat bahwa proses mental ini terlalu mementingkan pengertian saja, kurang memperhatikan perkembangan/ pembentukan sikap dan ketrampilan bagi siswa.

Teknik ini mungkin tidak memberikan kesempatan untuk berpikir secara kreatif.

4. Fase Pembelajaran Discovery

Langkah-langkah pembelajaran discovery diawali dengan pendahuluan mengapa penting mempelajari suatu materi, kemudian diikuti oleh pembelajaran yang mengaitkan antara materi yang diajarkan dengan kehidupan sehari-hari dimana siswa mengamati, menggolongkan, membuat dugaan, menjelaskan, menganalisis, memverifikasi, membuat kesimpulan suatu konsep dalam belajar. Dalam hal ini siswa dilibatkan dalam proses kegiatan pembelajaran melalui tukar pendapat, diskusi, presentasi, membaca sendiri, mencoba sendiri. Seperti contoh rencana pembelajaran dalam 2 jam pembelajaran untuk mengidentifikasi volume kubus dan balok pada tabel berikut. 


\begin{tabular}{|c|c|c|c|}
\hline \multicolumn{2}{|c|}{$\begin{array}{l}\text { Bentuk } \\
\text { Kegiatan }\end{array}$} & Langkah-langkah Pembelajaran & Waktu \\
\hline & $\begin{array}{l}\text { ndahuluan } \\
\text { Motivasi }\end{array}$ & $\begin{array}{l}\text { (1) Guru mengawali kegiatan pembelajaran dengan } \\
\text { mengucapkan salam. }\end{array}$ & $\begin{array}{l}10 \\
\text { menit }\end{array}$ \\
\hline & Apersepsi & $\begin{array}{l}\text { (2) Guru menunjukkan gambar } \\
\text { disamping dan } \\
\text { menanyakan kepada siswa } \\
\text { tentang permasalahan: } \\
\text { Pernahkah kalian } \\
\text { memperhatikan bak mandi } \\
\text { yang ada di rumah kalian? } \\
\text { Dapatkah kalian menentukan daya tampung bak } \\
\text { mandi tersebut? }\end{array}$ & \\
\hline & & $\begin{array}{l}\text { (3) Siswa diingatkan kembali oleh guru mengenai } \\
\text { unsur-unsur kubus dan balok. }\end{array}$ & \\
\hline C) & Iujuan & $\begin{array}{l}\text { (4) Guru menyampaikan tujuan pembelajaran yang } \\
\text { akan dicapai (nomor 5-6). }\end{array}$ & \\
\hline & $\begin{array}{l}\text { giatan Inti } \\
\text { Eksplorasi }\end{array}$ & $\begin{array}{l}\text { (1) Guru memberikan kubus satuan kepada masing- } \\
\text { masing kelompok. Siswa diminta menyusun } \\
\text { kubus atau balok dengan kubus satuan tersebut } \\
\text { (mengamati, mengerti, menggolongkan). }\end{array}$ & $\begin{array}{l}50 \\
\text { menit }\end{array}$ \\
\hline b) & Elaborasi & $\begin{array}{l}\text { (2) Siswa dikelompokkan dengan banyak anggota } \\
\text { masing-masing 4-5 siswa. } \\
\text { (3) Siswa diberikan Lembar Kegiatan Siswa (LKS) } \\
5.3 .3 \text { mengenai volume kubus dan balok. } \\
\text { (4) Masing-masing kelompok mengambil kubus } \\
\text { satuan dan membuat bangun ruang dengan } \\
\text { ukuran yang berbeda. } \\
\text { (5) Siswa mendiskusikan LKS } 5.3 .3 \text { secara } \\
\text { berkelompok (membuat dugaan dan } \\
\text { menjelaskan). } \\
\text { (6) Jika ada siswa atau kelompok yang mengalami } \\
\text { kesulitan maka guru memberikan } \\
\text { arahan/bimbingan. } \\
\text { (7) Siswa mempresentasikan hasil diskusi kelompok } \\
\text { (menjelaskan dan menganalisis). }\end{array}$ & \\
\hline & & $\begin{array}{l}\text { (8) Siswa bersama-sama guru membahas hasil } \\
\text { presentasi dan memberikan kesempatan }\end{array}$ & \\
\hline
\end{tabular}




bertanya tentang materi yang belum dipahami
berkaitan dengan pelajaran yang baru saja
dipelajari (reflecting dan questioning).
(9) Siswa diberikan soal oleh guru sebagai penilaian
(terlampir).
(10) Siswa mengerjakan soal evaluasi yang
diberikan oleh guru (memverifikasi dan membuat
kesimpulan).
(1) Siswa membuat rangkuman tentang volume 10
kubus dan balok. menit
(2) Siswa dan guru melakukan refleksi.
(3) Guru menugaskan kepada siswa untuk
mempelajari volume prisma dan limas untuk
pertemuan selanjutnya.
(4) Guru memberikan PR.

\section{Contoh Lembar Kegiatan Siswa}

Alat dan bahan : kubus satuan

Petunjuk : susunlah kubus satuan sesuai yang ada di tabel kemudian lengkapilah!
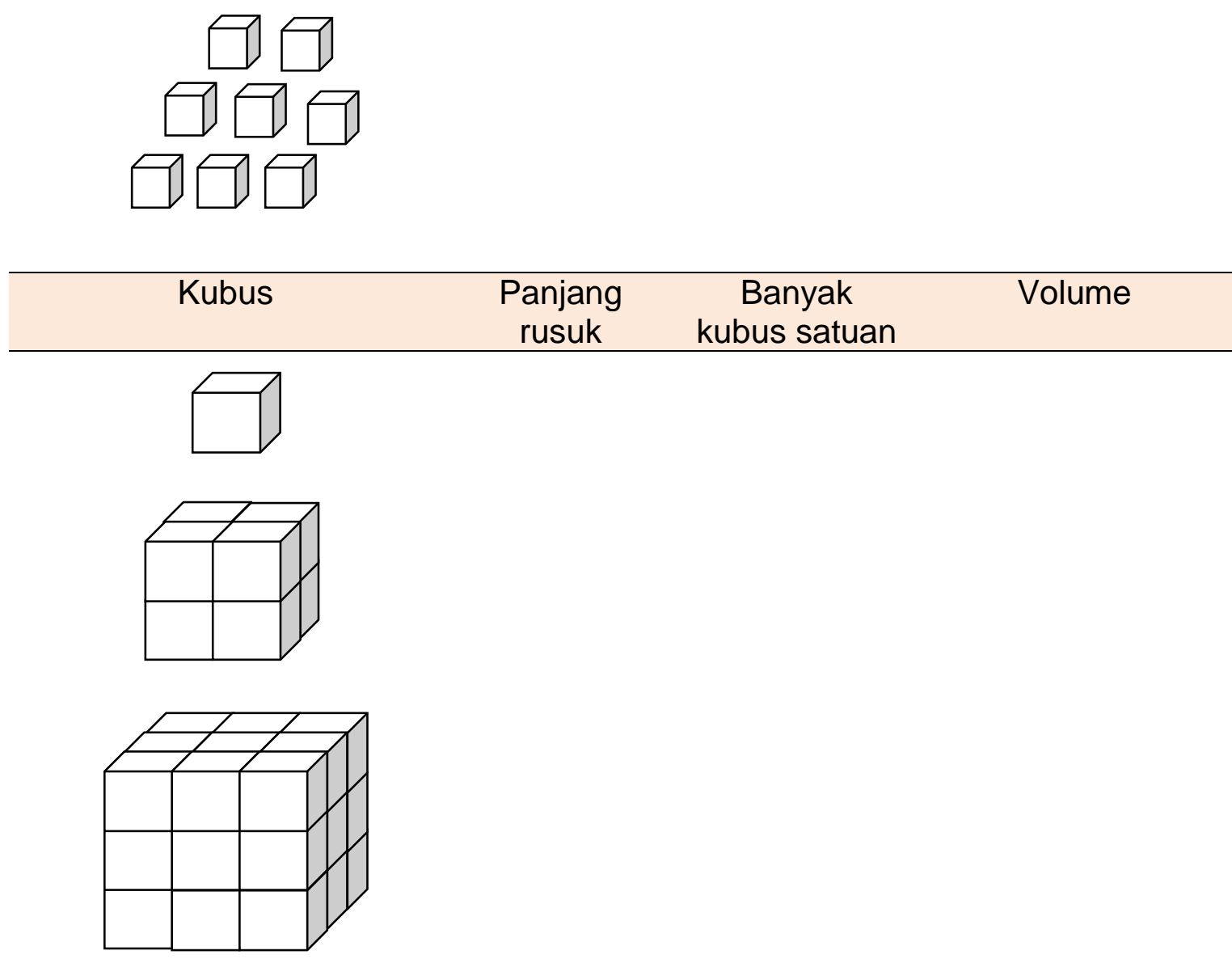


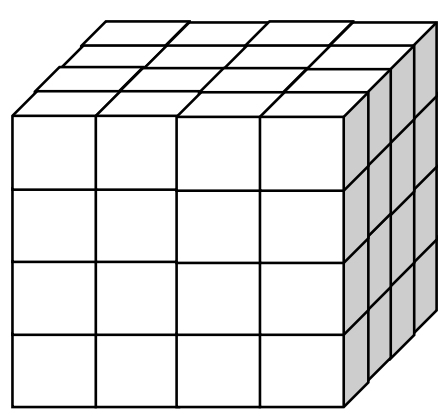

Dengan demikian, rumus menghitung volume kubus dengan panjang rusuk $r$ adalah:

$\mathbf{V}=\ldots \ldots \ldots$ atau $\mathbf{V}=\ldots$

Susunlah kubus satuan sesuai yang ada di tabel kemudian lengkapilah!

Balok Panjang Lebar Tinggi Banyak Volume kubus

satuan
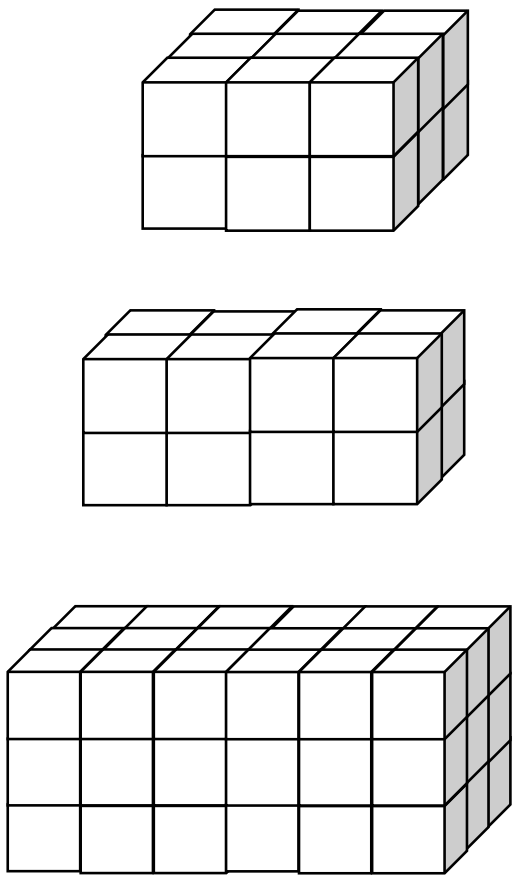


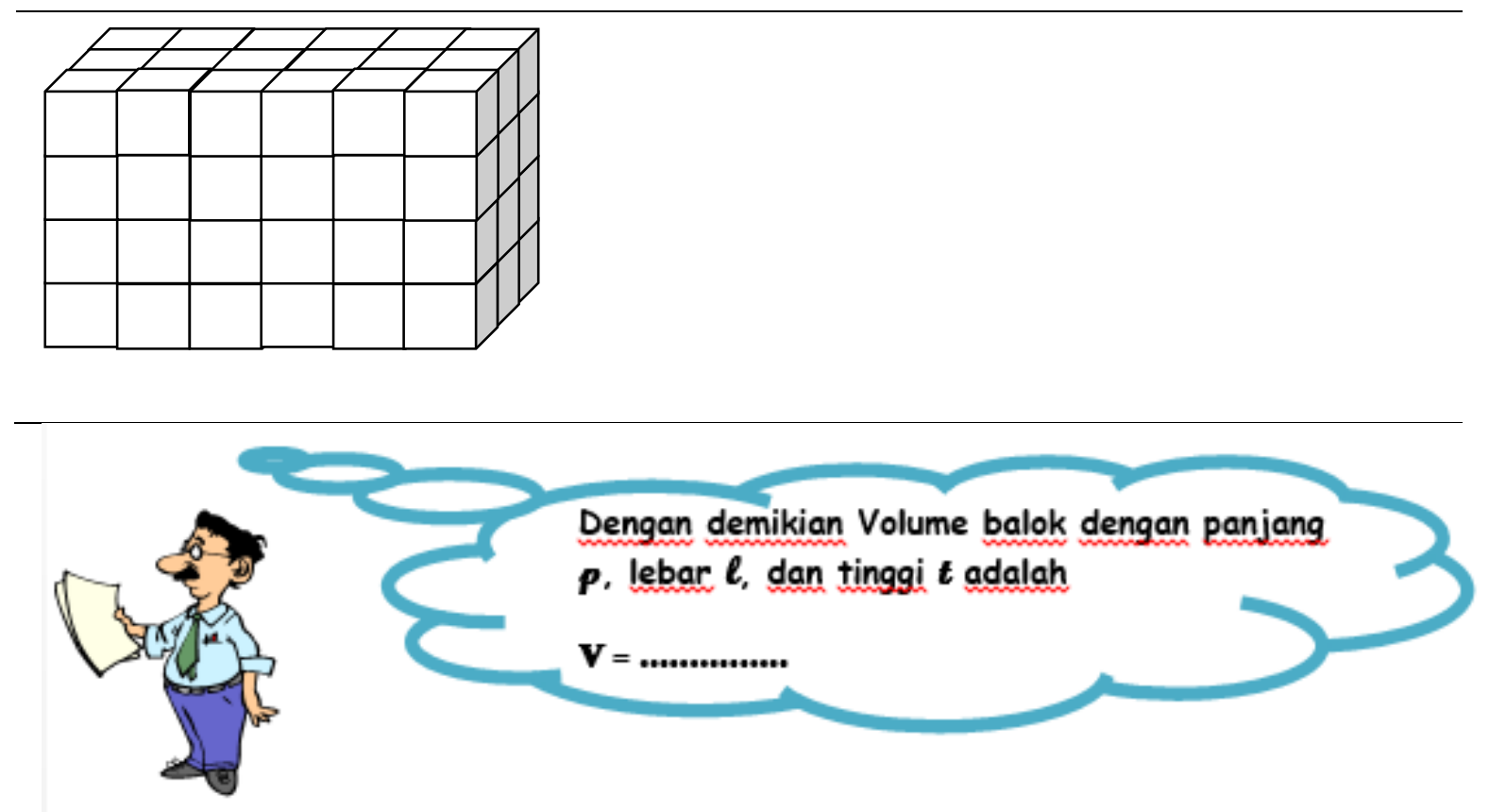

\section{SIMPULAN}

Pembelajaran

matematika merupakan proses interaksi belajar mengajar matematika antara siswa dan guru yang melibatkan segenap aspek di dalamnya untuk mencapai tujuan kurikulum agar proses pembelajaran berkembang secara optimal. Aspek pembelajaran berkaitan dengan konsep-konsep pokok yang harus melibatkan siswa secara aktif baik secara individu maupun kelompok. Pembelajaran discovery dimana siswa mengamati, menggolongkan, membuat dugaan, menjelaskan, menganalisis, memverifikasi, membuat kesimpulan suatu konsep dalam belajar. Dengan mempelajari pembelajaran discovery dan disertai dengan variasi metode dan media untuk meningkatkan kompetensi matematika siswa, guru hendaknya mengadakan inovasiinovasi dalam proses pembelajaran, salah satunya dengan menggunakan variasi pada proses pembelajaran matematika. Dengan adanya variasi pembelajaran inovatif seperti ini diharapkan akan mampu menciptakan pembelajaran matematika yang lebih bermakna yaitu pembelajaran matematika yang mengkonstruksi pengalaman belajar siswa.

\section{DAFTAR PUSTAKA}

Alfieri, L., Brooks, P.J., Aldrich, N.J., et.al. (2010). Does Discoverybased Instruction Enhance Learning?. Journal of Educational Psychology 2011, vol 103, no 1, 1-18. http://lexiconic.net/pedagogy/edu -103-1-1.pdf . Diambil pada tanggal 28 Juli 2017. 
Brown, A.H., Orlich, D.C., Harder, R.J., et al. (2007). Teaching strategies: a guide to effective instruction $\left(8^{\text {th }}\right.$ ed). New York: Houghton Mifflin Company.

Coffey, H. Discovery Learning in Practice.

http://www.learnnc.org/referenc e/discovery+learning. Diambil pada tanggal 28 Juli 2017.

Elliot, S.N., Kratochwill, R. T., Cook, L. J., et al. (2000). Educational psychology: effective teaching, effective learning. New York: The Mc Graw Hill Companies, Inc.

Lefrancois, G. R. 2000. Psychology for teaching. Belmont: Wadsworth.

Marpaung, Y. 2001. Pendekatan Realistik dan Sani dalam Pembelajaran matematika.Makalah.Disampaik an pada Seminar Nasional Pendidikan Matematika Realistik Indonesia,tanggal 14-15
November 2001. Yogyakarta: Universitas Sanata Dharma.

Moore, K. D. (2009). Effective instructional strategies: from theory to practice. Thousand Oaks, California: SAGE Publications, Inc.

Roestiyah, N.K. (2008). Strategi belajar mengajar: salah satu unsur pelaksanaan strategi belajar mengajar: teknik penyajian. Jakarta: Rineka Cipta.

Syaiful Bahri Djamarah. (2006). Strategi belajar mengajar (edisi revisi). Jakarta: Rineka Cipta.

Schunk, D. H. (2008). Learning theories: An educational perspective. ( $5^{\text {rd }}$ ed). Upper Saddle River, NJ: Pearson Education.

Slavin, R. E. (2006). Educational psychology: theory and practice. London: Pearson Education. 